\title{
PKM Kelompok Dasawisma di Kelurahan Kenali Asam Bawah
}

\author{
Tina Yuli Fatmawati ${ }^{1}$, Ariyanto $^{2}$, Dinda Anjani Putri ${ }^{3}$ \\ 1,2.,3 Program Studi D3 Keperawatan, STIKes Baiturrahim Jambi \\ Email: tinayulifatmawati@gmail.com
}

Submitted : 14/04/2020

Accepted: 21/04/2020

Published:16/06/2020

\begin{abstract}
The healthy living community movement (GERMAS) aims to increase awareness, willingness and the ability of people to behave in an effort to improve the quality of life. GERMAS is carried out as a reinforcement of community promotive and preventive efforts. Some observations made on the dasawiwma group do not have a family medicinal plant (TOGA) yet, partners are very hopeful that the provision of health education to the dasawisma group in order to better understand the benefits of TOGA. This dedication activity has been carried out in Kenali Asam Bawah Kelurahan with the target of dasawisma and the community, carried out in Juny 2019. Through this service the team facilitated, assisted the homeless and residents in identifying, identifying, and coping with public health problems. The team also helped prepare toga, demonstrations in making drinks from celery and soursop leaves, Provision of posters / booklets and TOGA boards
\end{abstract}

Keywords: celery, family medicinal plants, health education, soursop leaves

\begin{abstract}
Abstrak
Gerakan masyarakat hidup sehat (GERMAS) bertujuan untuk meningkatkan kesadaran, kemauan dan kemampuan masyarakat untuk berperilaku sehat dalam upaya meningkatkan kualitas hidup. GERMAS dilakukan sebagai penguatan upaya promotif dan preventif masyarakat. Observasi yang dilakukan pada kelompok dasawiwma sebagian belum memiliki tanaman obat keluarga ( TOGA), mitra sangat berharap diadakannya pemberian pendidikan kesehatan kepada kelompok dasawisma agar lebih memahami tentang manfaat TOGA. Kegiatan pengabdian ini telah dilaksanakan di Kelurahan Kenali Asam Bawah dengan sasaran kader dan warga khususnya RT 11 di Kelurahan Kenali Asam Bawah, dilaksanakan pada bulan Juni 2019. Melalui kegiatan pengabdian ini tim memfasilitiasi , membantu dasawisma dan warga dalam mengenal, mengidentifikasi, mengatasi masalah kesehatan masyarakat. Tim juga membantu menyiapkan toga, demonstrasi dalam pembuatan minuman dari seledri dan daun sirsak, Pemberian poster /booklet serta papan TOGA.
\end{abstract}

Kata Kunci: pendidikan kesehatan, seledri, sirsak, tanaman obat keluarga

\section{PENDAHULUAN}

Gerakan masyarakat hidup sehat" adalah gerakan bersama yang memiliki beberapa tujuan mulai menurunkan beban penyakit menular dan penyakit tidak menular, baik kesakitan, kematian maupun kecacatan, menghindarkan terjadinya penurunan produktivitas, menurunkan beban pembiayaan pelayanan kesehatan karena meningkatnya penyakit dan pengeluaran kesehatan. Perbaikan lingkungan dan perubahan perilaku kearah yang lebih sehat perlu dilakukan secara sistematis dan terencana oleh semua komponen bangsa. Untuk itu Gerakan
Masyarakat (GERMAS) menjadi sebuah pilihan dalam mewujudkan derajat kesehatan masyarakat yang lebih baik. Secara umum Germas bertujuan untuk meningkatkan kesadaran, kemauan dan kemampuan masyarakat untuk berperilaku sehat dalam upaya meningkatkan kualitas hidup. GERMAS dilakukan sebagai penguatan upaya promotif dan preventif masyarakat. Tujuan GERMAS, antara lain: 1) Menurunkan beban penyakit menular dan penyakit tidak menular, baik kematian maupun kecacatan; 2) Menghindarkan terjadinya penurunan produktivitas penduduk 3) Menurunkan beban 
pembiayaan pelayanan kesehatan karena meningkatnya penyakit dan pengeluaran kesehatan.

Keberhasilan gerakan masyarakat hidup sehat ini sangat tergantung pada partisipasi aktif semua stakeholder dan masyarakat. Masyarakat perlu digerakkan untuk memiliki kemampuan untuk melaksanakan semua fokus kegiatan tersebut dan dapat melaksanakan dalam kegiatan sehari-hari.Seluruh lapisan masyarakat harus terlibat dalam Germas Hidup Sehat, mulai dari Individu, keluarga dan masyarakat mempraktekkan pola hidup sehat sehari-hari.(Panduan GERMAS)

Untuk mewujudkan masyarakat hidup sehat, tanaman obat keluarga (TOGA) menjadi salah satu pilihan masyarakat. TOGA dapat dijadikan obat yang aman, tidak mengandung bahan kimia, murah dan mudah didapat. (Nurbaeti,2015).

Sejalan dengan peraturan pemerintah nomor 103 tahun 2014 tentang pelayanan kesehatan tradisional tentang pemberdayaan masyarakat yang menyatakan bahwa masyarakat dapat melakukan perawatan kesehatan secara mandiri dengan memanfaatkan tanaman obat keluarga (TOGA) sehingga diperoleh keluarga sehat secara mandiri. Upaya pengobatan tradisional dengan menanam tanaman obat keluarga adalah satu bentuk peran serta masyarakat dalam menunjang pembangunan kesehatan

Kelurahan Kenali Asam Bawah terletak di sebelah Kota Jambi dengan luas wilayah 140,70 hektar . Kelurahan Kenali Asam Bawah berbatasan sebelah Barat dengan Mayang Mengurai sebelah Timur berbatasan dengan Kenali Asam Atas sebelah Utara berbatasan dengan Suka Karya dan sebelah Selatan berbatasan dengan Muaro Jambi. Kelurahan Kenali Asam Bawah terdapat 48 RT yang terdiri dari 4739 kepala keluarga dengan jumlah penduduk 16.518 jiwa, jenis pekerjaan sebagian besar tani ( 36650 laki-laki dan 3600 perempuan). (Profil Kel.Kenali asam bawah 2016). Dari survei yang telah kami lakukan pada bulan Januari 2019 dengan ketua TP PKK sekaligus ketua dasawisma, kami menemukan beberapa masalah diantaranya beberapa Dasa Wisma masih sedikit pengetahuan tentang masalah kesehatan dan manfaat TOGA. Sebagian kelompok dasawiwma tidak memiliki tanaman obat keluarga. Dengan permasalahan tersebut sangat memungkinkan terjadinya peningkatan angka kesakitan dimasyarakat. Mitra sangat berharap diadakannya pemberian pendidikan kesehatan kepada kelompok dasawisma agar lebih memahami tentang masalah kesehatan. Melalui kegiatan pengabdian ini kami dan tim akan memfasilitiasi, membantu dasawisma/masyarakat dalam mengenal, mengidentifikasi, mengatasi masalah kesehatan khususnya RT 11 di Kelurahan Kenali Asam Bawah.

Secara rinci masalah yang dihadapi oleh mitra dapat dilihat pada uraian dibawah ini:

a. Program Dasawisma masih belum berjalan dengan baik/belum optimal. Hal ini sangat disayangkan mengingat sebagian besar kader tidak bekerja (ibu rumah tangga) yang memiliki banyak waktu luang untuk menjalankan kegiatan program dasawisma.

b. Ketua TP PKK mengharapkan penyuluhan pentingnya tanaman Obat keluarga disetiap rumah

c. Masyarakat sebagian besar belum memahami tentang masalahmasalah kesehatan dan bagaimana cara peningkatan status kesehatan

d. Kader/warga belum memaksimalkan lahan dengan tanaman obat keluarga. 


\section{TARGET DAN LUARAN}

Target yang dicapai pada Pengabdian masyarakat ini adalah :

a. Sosialisasi pentingnya tanaman obat keluarga (TOGA)

b. Penanaman tanaman obat keluarga (TOGA) oleh warga

b. Demonstrasi pembuatan herbal Luaran dari kegiatan pengabdian ini yaitu:

a. Publikasi artikel pada jurnal pengabdian masyarakat (draf)

b. Tersedianya Media KIE ( poster dan boklet efektif)

c. Terjadi peningkatan pengetahuan kader dan warga dalam memanfaatkan tanaman obat keluarga.

\section{METODE PELAKSANAAN}

Kegiatan pengabdian ini di laksanakan di Kelurahan Kenali Asam Bawah khususnya di RT 11 dengan sasaran kader dan warga yang dilaksanakan pada bulan Juni 2019.

\section{Pelaksanaan Kegiatan}

Tahapan pelaksanaan kegiatan pengabdian kepada masyarakat ini adalah sebagai berikut:

\section{Persiapan}

a) Koordinasi dan menyamakan persepsi

b) Menyiapkan tanaman obat keluarga (TOGA)

\section{Pelaksanaan Kegiatan}

a) Demonstrasi Tanaman obat keluarga

b) Edukasi pada warga melalui media poster dan leafleat.

c) Serah terima poster/bookletTanya jawa $b$

d) Penutupan

\section{Monitoring dan Evaluasi}

Monitoring dan evaluasi (Monev) dilakukan secara langsung kepada sasaran. Cakupan Monev dalam kegiatan ini meliputi evaluasi program dasawisma dan penyusunan laporan

\section{HASIL DAN PEMBAHASAN}

Kegiatan pengabdian masyarakat di Kelurahan Kenali Asam Bawah khususnya di RT 11 telah dilaksanakan sesuai dengan rencana. Dalam pelaksanaan pengabdian masyarakat diperoleh hasil:

1. Sosialisasi kegiatan, dengan melibatkan ketua RT dan kader.

2. Pemberian/pengadaan tanaman obat keluarga

3. Demonstrasi dalam pembuatan minuman dari seledri dan daun sirsak

4. Pemberian poster/booklet

Gaya hidup kembali ke alam, saat ini semakin meningkat, seiring dengan kesadaran masyararakat terhadap bahaya yang ditimbulkan oleh bahan bahan kimia, baik yang terkandung dalam makanan ataupun obat-obatan. Dampak dari itu penggunaan obat-obat tradisional sudah kembali membudaya di Indonesia. Pada kegiatan pengabdian kali ini tim memberikan edukasi dan demonstrasi tentang manfaat daun sirsak dan seledri yang sangat mermanfaat untuk terapi asam urat dan hipertensi.

Pada kegiatan sebelumnya tim juga melaksanakan kegiatan pengabdian masyarakat yang sama dengan sasaran kelompok dasawisma. Target sasaran berjumlah 10 orang dalam satu kelompok dasawima khusunya di Kelurahan Kenali Asam Bawah RT 047. Tujuan dari pengabdian masyarakat ini diharapkan setelah mengikuti sosialisasi Dasawisma Ketua kelompok mampu memahami dan mau memberikan motivasi kepada anggota kelompoknya tentang pentingnya penanaman TOGA (Nurfitriani, 2019).

Menurut Nurbaeti 2015, Tanaman obat keluarga pada hakekatnya adalah tanaman berkhasiat yang ditanam di lahan pekarangan yang dikelola oleh keluarga. Salah satu fungsi dari TOGA adalah sebagai sarana untuk mendekatkan tanaman obat kepada upaya-upaya kesehatan masyarakat meliputi preventif, promotif dan kuratif. Untuk mendorong, menggerakkan dan memberikan pendidikan kesehatan serta 
memotivasi masyarakat dalam memiliki serta memanfaatkan TOGA maka perlu pembinaan secara intensif kepada masyarakat sehingga tercipta masyarakat yang sehat serta produktif.

Salah satu Tanaman obat keluarga yang kita kenal antara lain :

1) Daun dewa. Beberapa manfaaat daun dewa untuk kesehatan Mengobati kanker payudara, Mengobati penyakit jantung, Mengobati perdarahan atau pembengkakan payudara, Mengobati batuk dan muntah darah, Mengobati penyakit stroke .

2) Jahe. Manfaat dari jahe untuk kesehatan Mengatasi masalah pencernaan, Mengurangi mual, Mengurangi rasa sakit atau nyeri, urat sayaraf lemah, mengobati luka yang berbau, Membantu proses detoksifikasi dan mencegah penyakit kulit, Melindungi dari penyakit kanker.

3) Kunyit. Manfaat dari kunyit untuk kesehatan: Obat untuk pernapasan, Obat untuk pencernaan, mengobat radang usus buntu, amandel, asma, Obat anti nyeri dan antipiretik, Menambah produksi ASI, Anti oksidan, anti radang.

4) Kencur. Manfaat dari kencur untuk kesehatan: Obat batuk, radang lambung, Muntah-muntah, Menghilangkan stress, Obat diare, Menambah nafsu makan, Mengatasi radang lambung

5) Seledri. Daun seledri mengandung gizi dna nutrisi yang sangat baik untuk para penderita hipertensi seperti kandungan phthalides, kumarin dan juga apigenin. Oleh karena itu menggunakan daun seledri sebagai bahan diet sehat bagi penderita hipertensi adalah hal yang sangat dianjurkan. Zat lainnya yang ada di dalam seledri adalah kandungan kumarin. Kumarin sangat bermanfaat bagi tubuh karena mampu menghalau datangnya zat karsinogenik yang lebih dikenal dengan istilah radikal bebas (Lingga, 2009).

6) Daun Sirsak. Manfaat mengonsumsi daun sirsak selanjutnya adalah untuk membantu mengobati asam urat. Caranya, ambil enam hingga 10 lembar daun sirsak yang sudah tua tetapi masih hijau, lalu cuci bersih. Rebus daun dalam dua gelas air dan didihkan sampai tersisa satu cangkir air. Ramuan ini harus diminum dua kali sehari, yaitu pagi dan sore hari untuk hasil yang maksimal.

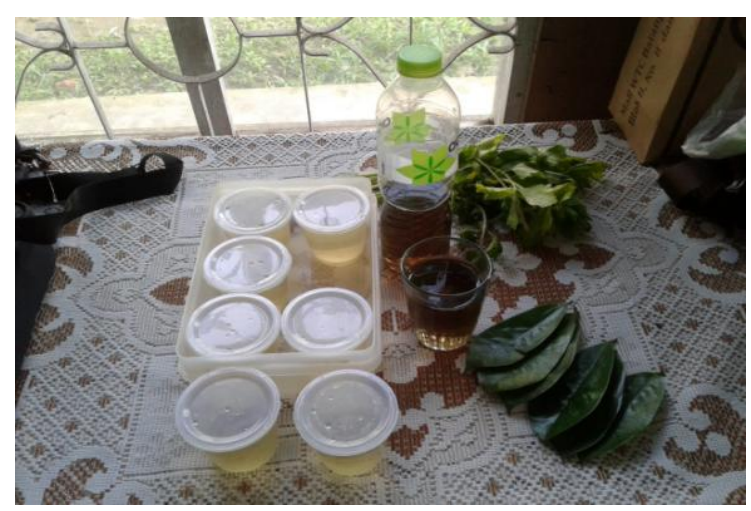

Gambar 1. Pemberian ramuan daun sirsak dan seledri

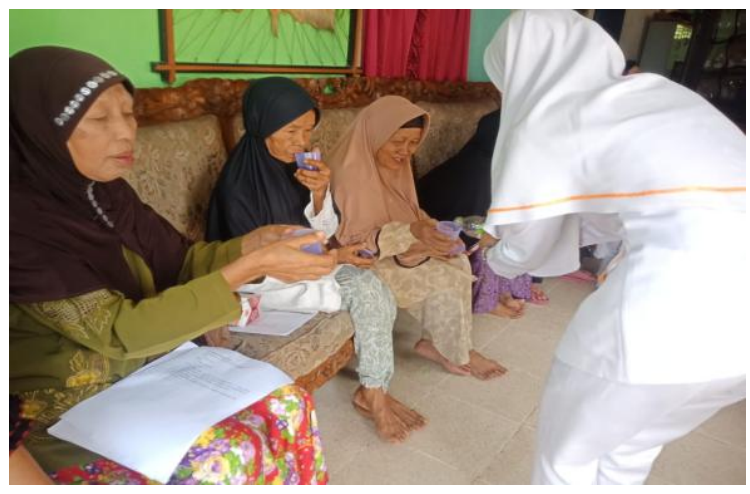

Gambar 1. Pemberian Minuman dari daun sirsak dan seledri

\section{KESIMPULAN DAN SARAN}

\section{Kesimpulan}

Sebagian besar Kader dan warga memahami bagaimana manfaat tanaman obat keluarga. Kader juga mampu membuat ramuan tradisional secara mandiri di rumah

\section{Saran}

Diharapkan kepada Ketua TP PKK Kelurahan Kenali Asam Bawah agar selalu memotivasi kepada kader dan warga khususnya dalam pemanfaatan tanaman keluarga 


\section{UCAPAN TERIMAKASIH}

Tim Pengabdian mengucapkan terimakasih kepada STIKes Baiturrahim Jambi atas dukungan moril serta materiil sehingga kegiatan ini dapat terlaksana dengan baik.

\section{DAFTAR PUSTAKA}

Dinas Kesehatan Propinsi Jambi, 2013, Profil Kesehatan Propinsi Jambi.

Kelurahan Kenali Asam Bawah, 2016, Profil Kesehatan Kelurahan Kenali Asam Bawah

Lingga. 2009. Resep- Resep Obat Tradisional. Jakarta : Katalog Dalam Terbitan (KDT)

Nurbaiti (ed), 2015. Buku saku Tanaman Obat keluarga (TOGA), Balai Pengkajian Teknologi Pertanian (BPTP) Jawa Barat.

N Nurfitriani, TY Fatmawati. 2019. Pemberdayaan Kelompok Dasawisma Dalam Pemanfaatan Tanaman Obat Keluarga (Toga) Di Kelurahan Kenali Asam Bawah, Jurnal Abdimas Kesehatan. (JAK) Vol 1, No. 3, November 2019,223-227 http://jak.stikba.ac.id/index.php/jak/a rticle/view/68, diakses tanggal 14 April 2020. 